\title{
PEMIJAHAN IKAN LELE DENGAN TEKNIK PEMIJAHAN ALAM (NATURAL SPAWNING) DAN PEMIJAHAN SEMI ALAMI (INDUCED SPAWNING)
}

\author{
Pungky Slamet Wisnu Kusuma ${ }^{1)}$, Sukarjati' ${ }^{2)}$, Tony Susilo Wibowo ${ }^{3)}$ \\ ${ }^{1,2}$ Fakultas Matematika dan Ilmu Pengetahuan Alam, Universitas PGRI Adi Buana Surabaya \\ Email : slametswk@yahoo.com, sukarjati@ymail.com \\ ${ }^{3}$ Fakultas Ekonomi, Universitas PGRI Adi Buana Surabaya \\ Email: tonysus_sw@yahoo.com
}

\begin{abstract}
Abstrak
Keinginan kelompok tani lele Sumber Rejeki untuk melakukan pembenihan sendiri, tetapi sering gagal, menyebabkan pendapatan rendah dan tidak berkelanjutan. Selain itu, kelompok tani juga ingin meningkatkan pengetahuan dan keterampilan mereka terkait dengan prosedur pemijahan ikan lele secara alami dan semi-alami hingga benih ikan lele siap dijual. Tujuan dari pelatihan dan pendampingan adalah untuk menemukan solusi terobosan untuk teknologi yang mudah digunakan untuk memacu pematangan gonad, mempercepat pemijahan dan produksi massal benih secara terus menerus dan terus menerus dengan teknologi induksi laserpuncture. Mengukur keberhasilan pelatihan dan pendampingan peserta dapat mengoperasikan unit tusukan laser dengan benar, dapat menentukan lokasi titik reproduksi dengan benar dan dapat menginduksi induk lele jantan dan betina dengan teknologi tusukan laser dengan benar dan induk lele yang diinduksi oleh tusukan laser dapat menumbuhkan gonad, cepat memijah dan memproduksi benih lele dalam jumlah besar dan terus menerus yang siap dijual.
\end{abstract}

Kata kunci: laserpunktur, pelatihan dan pendampingan, induk lele matang gonad

\begin{abstract}
The desire of the Sumber Rejeki catfish farmer group to do their own hatchery, but often failures, this causes low income and is not continuous. In addition, the groups of farmers also want to increase their knowledge and skills related to the procedures for spawning catfish naturally and semi-naturally until catfish seeds are ready for sale. The aim of training and mentoring is to find a breakthrough solution for easy-to-use technology to spur gonad maturation, accelerate spawning and mass production of seeds in a continuous and continuous manner with laserpuncture induction technology. Measuring the success of training and mentoring participants can operate the laserpuncture unit correctly, can determine the location of the reproductive acupoint correctly and can induce male and female catfish parents with laserpuncture technology correctly and the catfish parent induced by laserpuncture can mature gonads, quickly spawning and producing catfish seeds in bulk and continuously that are ready for sale.
\end{abstract}

Keywords: laserpuncture, training and mentoring, mature gonad catfish parents

\section{PENDAHULUAN}

Desa Cangkringturi Kecamatan Prambon Sidoarjo mempunyai dua kelompok pembudidaya ikan lele yaitu satu kelompok ada di Dusun Cangkring dan satu kelompok yang lain ada di Dusun Turi nama kelompok pembudidaya ikan lele tersebut adalah kelompok Ternak Sumber Rejeki. Sedangkan ketua kelompok Dusun Cangkring adalah
Bpk. Kustaman dan ketua kelompok Dusun Turi adalah Bpk. Abdul Karim Darsono.

Bapak Abdul Karim Darsono telah bergerak di budidaya ikan lele sejak tahun 2000 jenis kolam yang diginakan untuk budidaya adalah kolam tanah dengan ukuran $3 x 6$ sebanyak 8 petak. Air kolam yang digunakan untuk mengairi kolamnya diperoleh dari air sungai dan pembuangannya 
juga dialirkan ke sungai. Beliau bergerak dalam bidang pembesaran saja. Sedangkan Bapak Kustaman membudidayakan ikan lele sejak tahun 2014. Sebelum budidaya lele beliau beternak sapi. Jenis kolam untuk ikan lelenya adalah kolam terpal ukuran 3x6m persegi ada 9 petak. Dalam pembenian pada kedua kelompok pembudidaya lele tidak berhasil. Hal ini menunjukkan kurangnya pengetahuan dan ketrampilan dalam budidaya ikan lele.

Keinginan kelompok Ternak Sumber Rejeki melakukan pembenihan ikan lele sendiri karena sering terjadi kegagalan, hal inilah yang menyebabkan pendapatan pembudidaya ikan lele rendah dan tidak ajeg. Selain itu para kelompok pembudidaya khususnya ikan lele juga menginginkan peningkatan pengetahuan dan ketrampilan yang berkaitan dengan cara memijahkan ikan secara alami dan semi alami sampai dihasilkan benih yang siap untuk dijual. Untuk itu perlu dicari solusinya dengan cara mencari terobosan teknologi tepat guna yang dapat memacu pematangan gonad, mempercepat pemijahan dan mempercepat produksi benih secara massal.

Teknologi tepat guna tersebut adalah teknologi laserpunktur. Pemanfaatan soft laser sudah diaplikasikan dalam penelitian Kusuma dkk (2007) mengetrapkannya pada ikan lele yang di induksi laserpunktur pada titik reproduksi tepatnya di $2 / 3$ bagian ventral tubuh selama 15 detik, setiap seminggu sekali menunjukkan ada pengaruh pada kecepatan pematangan gonad dan induk siap untuk dipijahkan selain itu induksi laserpunktur dapat memperpendek siklus reproduksinya.

Dariil hasil penelitian tersebut di atas perlu dilakukan sosialisasi tentang teknologi laserpunktur sebagai upaya mempercepat produksi benih khususnya pada kelompok pembudidaya ikan di kelompok petani Ternak Sumber Rejeki yang bergerak dalam mempersiapkan induk lele matang gonad siap dipijahkan untuk menghasilkan benih di Desa Cangkringturi Kecamatan Prambon Sidoarjo sehingga dapat diperoleh induk dan benih setiap saat dapat tersedia tanpa memperhatikan musim secara massal dan kontinyu.

Alternatif tersebut diambil dengan pertimbangan efisiensi dan efektivitas pencapaian tujuan kegiatan ini. Kegiatan pelatihan untuk sosialisasi teknologi laserpunktur ini mengintegrasi pendekatan teori dan praktis. Teoritis dalam arti konsep teknologi laserpunktur untuk pengadaan induk lele matang gonad siap untuk dipijahkan serta untuk mempercepat produksi benih secara massal dan kontinyu yang diterapkan berdasarkan pada pengkajian secara ilmiah, sedangkan aplikasinya sampai dihasilkannya benih oleh pembenih lele. Oleh karena itu, memberikan pelatihan pada kelompok pembenih lele agar para peserta pelatihan tepat melakukan induksi laserpunktur pada titik reproduksi, trampil mengoperasikan laserpunktur dan dapat mengaplikasikannya dalam budidaya lele di kolam masing-masing untuk mempercepat penyediaan induk matang gonad siap dipijahkan dan benih ikan lele secara massal dan kontinyu.

\section{METODE PELAKSANAAN}

Mempersiapkan segala sesuatu yang berkaitan dengan kegiatan pelatihan dalam sosialisasi teknologi laserpunktur untuk mempercepat pengadaan induk matang gonad siap untuk dipijahkan guna mempercepat produksi benih secara massal dan kontinyu.

a. Pelaksanaan sosialisasi laserpunktur dalam pelatihan ini dilakukan di salah satu rumah milik ketua kelompok pembenih ikan di Desa Cangkringturi Kecamatan Prambon Sidoarjo.

b. Dilakukan dempond di kolam salah satu kelompok peserta pelatihan dan pendampingan.

c. Pendampingan ke setiap pembenih lele yang telah mengikuti sosialisasi laserpunktur untuk langsung mengaplikasikannya di kolam masing-masing dan membuat report hasil lele yang dilaser serta hasil penjualan sampai pelaksanaan berakhir. 
d. Dilakukan pelatihan dan pendampingan tentang tata cara teknik pemijahan hingga dihasilkan benih ikan lele.

e. Menunjukkan tentang ciri-ciri induk lele jantan matang gonad yaitu: Memiliki alat kelamin tampak jelas dan meruncing, Tulang kepala lebih mendatar dibanding betinanya, Memiliki warna dasar badannya hitam (gelap), Siklus umur induk jantan di atas 8 bulan.

f. Menunjukkan tentang ciri-ciri induk lele betina matang gonad yaitu: Memiliki ukuran Kepala lebih besar dibanding induk lele jantan, Memiliki Warna kulit dada agak terang dengan urogenital papilla (kelamin) berbentuk oval (bulat daun), berwarna kemerahan, lubangnya agak lebar dan terletak di belakang anus. Memiliki gerakannya lambat, tulang kepala pendek dan agak cembung dengan struktur perutnya lebih gembung dan lunak. BiIa bagian perut di stripping secara manual dari bagian perut ke arah ekor akan mengeluarkan butiran kekuning-kuningan (ovum atau telur).

\section{Pemijahan alami (Natural Spawning):}

1. Dilakukan dengan memasukkan induk ikan lele bersama-sama antara jantan dan betina siap pijah pada bak pemijahan, Sebelumnya, bak dikeringkan selama 2-4 hari. Selanjutnya bak diisi dengan air setinggi $25-30 \mathrm{~cm}$ dan membiarkan air mengalir selama pemijahan. Bersamaan dengan itu pasang atau masukan kakaban secukupnya untuk meletakkan telur.

2. Bila sudah siap, induk lele betina dan jantan yang sudah matang gonad dimasukkan ke dalam air pada siang atau sore hari.

3. Langkah selanjutnya adalah mengamati pasangan lele tersebut sampai berpijah di keesokan harinya.
4. Lele merupakan ikan yang bersifat kanibal, sehingga untuk menghindari induk lele memakan telurnya sendiri, maka kedua induk harus segera dipindahkan setelah memijah ke tempat lain dan telur dibiarkan menetas di tempat tersebut.

\section{Langkah pemijahan semi alami (Induced Spawning):}

1. Persiapan induk yang akan dipijahkan: Bobot indukan yang baik setidaknya mencapai 1-1,5 kg. Setelah calon-calon indukan cukup umur dan ukuran, pilih indukanindukan yang terlihat bugar, bebas penyakit dan bentuk tubuh yang bagus untuk proses pemijahan.

2. Indukan yang akan dipijahkan sebaiknya dipelihara dalam kolam khusus secara terpisah antara jantan dan betina agar tidak terjadi pembuahan diluar rencana.

3. Kolam khusus berfungsi untuk memelihara induk sampai matang gonad dan induk siap untuk dipijahkan.

4. Berikan pakan dengan mutu baik dengan kandungan protein $35 \%$ untuk mempercepat kematangan gonad. Jumlah pakan yang harus diberikan pada induk setidaknya 3$5 \%$ dari bobot tubuhnya setiap hari dan diberikan dengan frekuensi 2-3 kali sehari.

5. Kepadatan kolam untuk pemeliharan indukan ini tidak boleh lebih dari 6 ekor per $\mathrm{m} 2$ dan harus dipisahkan agar tidak terjadi pemijahan sebelum diberikan perlakuan.

6. Dari kolam ini indukan lele yang memenuhi kriteria matang gonad, diambil untuk dipijahkan. 


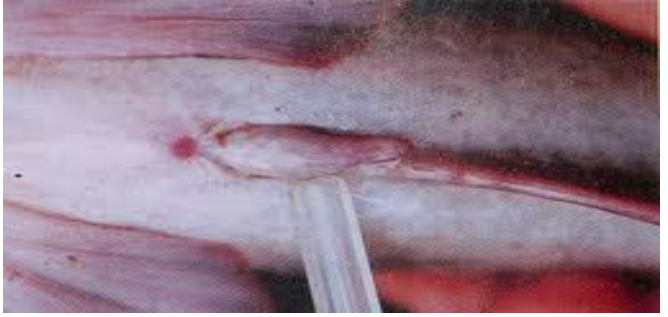

Gambar 1. Induk Jantan Matang

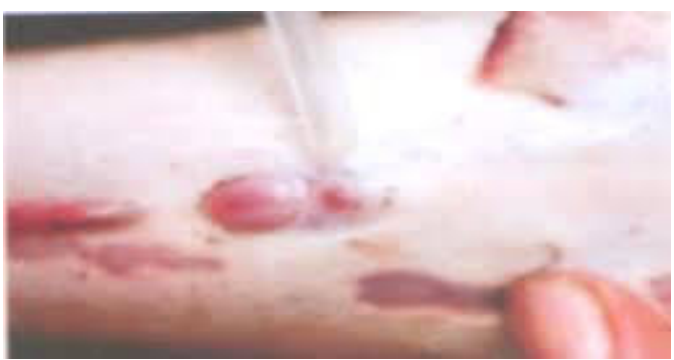

Gambar 2. Induk Betina Matang

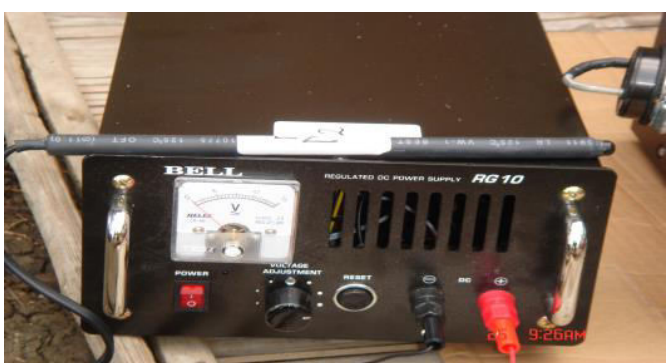

Gambar 3. Laserpunktur

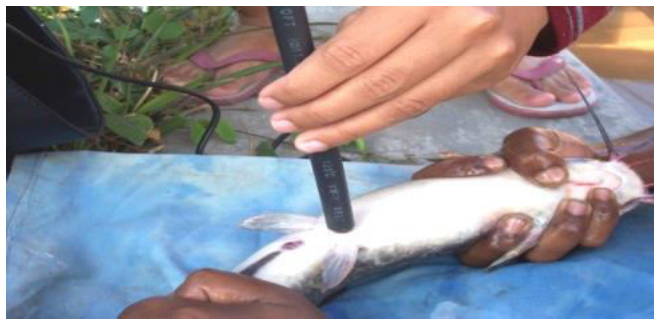

Gambar 4. Letak Titik Induksi

\section{Persiapan induk yang akan dipijahkan:}

1. Bobot indukan yang baik setidaknya mencapai 1-1,5 kg. Setelah caloncalon indukan cukup umur dan ukuran, pilih indukan-indukan yang terlihat bugar, bebas penyakit dan bentuk tubuh yang bagus untuk proses pemijahan.

2. Indukan yang akan dipijahkan sebaiknya dipelihara dalam kolam khusus secara terpisah antara jantan dan betina agar tidak terjadi pembuahan diluar rencana.

3. Kolam khusus berfungsi untuk memelihara induk sampai matang gonad dan induk siap untuk dipijahkan.

4. Berikan pakan dengan mutu baik dengan kandungan protein 35\% untuk mempercepat kematangan gonad. Jumlah pakan yang harus diberikan pada induk setidaknya 3$5 \%$ dari bobot tubuhnya setiap hari dan diberikan dengan frekuensi 2-3 kali sehari.

5. Kepadatan kolam untuk pemeliharan indukan ini tidak boleh lebih dari 6 ekor per $\mathrm{m} 2$ dan harus dipisahkan agar tidak terjadi pemijahan sebelum diberikan perlakuan.

6. Dari kolam ini indukan lele yang memenuhi kriteria matang gonad, diambil untuk dipijahkan.

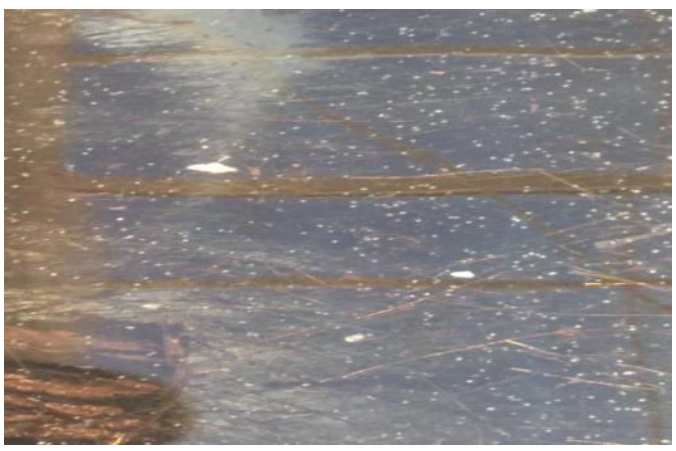

Gambar 5. Telur yang dibuahi

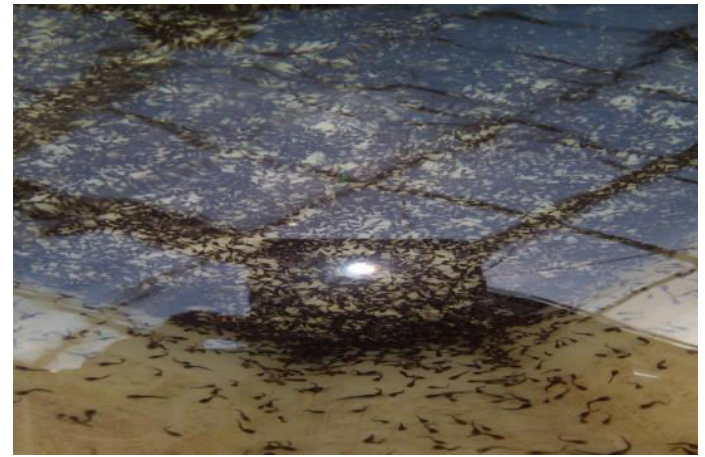

Gambar 9. Benih lele 
Tabel 1. Parameter Kualitas Air

\begin{tabular}{ll}
\hline $\begin{array}{l}\text { Kualitas Air Media } \\
\text { Hidup Lele } \\
\text { Parameter }\end{array}$ & $\begin{array}{l}\text { Nilai yang } \\
\text { dianjurkan }\end{array}$ \\
\hline Suhu & $25^{\circ} \mathrm{C}-30^{\circ} \mathrm{C}$ \\
pH & $6,5-8,6$ \\
Laju pergantian air & $(10-15) \%$ perhari \\
Ketinggian air & $50 \mathrm{~cm}-70 \mathrm{~cm}$ \\
Kecerahan & $25 \mathrm{~cm}-35 \mathrm{~cm}$ \\
\hline
\end{tabular}

\section{HASIL DAN PEMBAHASAN}

Dari hasil evaluasi selama pelatihan dan pendampingan PKM ini dapat diketahui bahwa (1) Keberhasilan pemijahan dengan menggunakan teknologi laserpunktur dan (2) Peserta mau menerapkan teknologi laserpunktur ini bergantung pada:

1. Adaptasi induk di kolam pemeliharaan, minimal 10 hari agar induk lele tidak stress dan nafsu makannya membaik

2. Induk lele harus diberi pakan berkualitas baik sesuai dengan SOP yang sudah ditentukan kelompok pembenih lele Desa Cangkringturi agar kualitas telur dan sperma bagus sehingga telur terfertilisasi dapat menetas sampai menjadi benih.

3. Pada saat lele dilakukan induksi laser punktur, induk diambil menggunakan waring, selanjutnya diambil menggunakan seser dan ditampung dalam box plastik berisi air kolam dan segera dibawa dekat tempat induksi laser dengan kepala ditutup dengan handuk atau kaos basah agar mengurangi stress dan segera dikembali kan ke tempat asalnya tanpa mengganti airnya.

4. Waktu induksi laserpunktur dilakukan secara periodik dan durasinya setiap 15 hari sekali. Dihimbau tidak menunda waktu induksi agar telur yang seharusnya sudah matang dan siap dipijahkan bila tidak segera dipijahkan telur yang telah matang diresorbsi kembali sehingga kondisi gonadnya tidak matang kembali dan warna alat kelaminnya menjadi putih kembali.

5. Pelopor penerapan teknologi laserpunktur di kelompok pembudidaya ikan Sumber Rejeki adalah Bpk Kustaman sebagai ketua kelompok. Beliau sudah mengaplikannya sampai sekarang untuk mempercepat pemijahan dan telur setelah dibuahi menetas dan menyebar rata di kolam pemijahan dengan keberhasilan telur yang menetas sekitar $90 \%$.

6. Setelah mengetahui ada anggota yang berhasil memijahkan dengan teknologi laserpunktur dan hasilnya baik baru ada anggota lain yang mencobanya. Mereka tidak mau mencoba-coba dulu takut gagal yang berakibat merugi.

7. Mereka beranggapan bahwa dengan kawin alami saja dan dengan pemberian induk berkualitas bagus serta pakan yang brkualitas sudah menguntungkan.

Dari hasil pelatihan dan pendampingan PKM ini dapat diketahui bahwa peserta pelatihan ini sudah dapat mengaplikasikan induksi laserpunktur di titik reproduksi dapat merangsang dan mempercepat induk lele jantan dan betina matang gonad, cepat memijah dan cepat menghasilkan benih secara massal untuk dibesarkan atau untuk dijual benihnya.

\section{KESIMPULAN}

a. Teknologi laserpunktur trbukti dapat mempercepat penyediaan induk lele matang gonad yang siap dipijahkan untuk memperoleh benih secara massal dan kontinyu.

b. Memberikan keuntungan bagi kelompok pembudidaya ikan lele dari segi pengetahuan dan keterampilan SDM, selain itu juga memberikan keuntungan secara ekonomis yaitu pendapatannya meningkat. 


\section{REFERENSI}

Adewumi, A.A., V.F. Olaleye and E.A. Adesulu. 2005. Egg and sperm quality of the African catfish, Clarias gariepinus (Burchell) broodstock fed differently heated soybean-based diets. Research J. of Agric and Biol Sce 1(1): 17-22.

Hariani, D. and P.S.W. Kusuma. 2009. Biostimuli reproduksi ikan lele Dumbo (Clarias gariepinus) betina dengan penembakan laserpunktur. Jurnal Berkala Penelitian Hayati. PBI Cabang Jawa Timur. Edisi Khusus. 01 Desember 2009, 3D:79-83.

Hariani, D dan P.S.W Kusuma, dan M.S. Widodo, 2010. Pemberdayaan kelompok pembenih lele untuk peningkatan produksi benih menggunakan laserpunktur sebagai upaya peningkatan pendapatan di desa Krecek, Kecamatan Pare, Kabupaten Kediri. Jurnal Aksi. Vol.12.No. 2. Hal 80-88.

Hossain, Q., M.. Hossain.and S. Parween. 2006. Artificial breeding and nursery practices of Clarias batrachus (Linnaeus, 1758). Sci World, Vol. 4, No. 4, July 2006.

Ingram, B., S. Sungan., G. Gooley., S.Y. Sin., D.Tinggi dan S.S. De Silva. 2005. Induced spawning, larval development and rearing of two indigenous Malaysian mahseer. Tor tambroides and $\mathrm{T}$. deouronensis. Aquaculture Resch 36:1001-1014.

Kelly, A.M. 2004. Revision.Channel catfish broodfish management.SRAC

Publication No. 1802.United States Department of Agriculture, Cooperative State Research, Education, and Extension Service.

Kusuma, P.S.W; Hariani, D; Mukti, A.T dan Satyantini, W.H. 2007. Penyediaan broodstock ikan lele dumbo (Clarias gariepinus) menggunakan teknologi laserpunktur sebagai upaya penyedian benih skala massal.Laporan
Penelitian APBD Provinsi Jawa Tengah TA 2007.

Kusuma, P.S.W; dan D.Hariani, 2008. Teknologi laserpunktur untuk mempercepat pematangan gonad ikan lele Dumbo. Jurnal Penelitian Matematika dan Sains FMIPAUNESA, 15(2):14-127, Desember 2008. ISSN : 0852-0518.

Kusuma, P.S.W. 2013. Mekanisme pelepasan hormone gonadotropin ikan lele (Clarias sp) setelah dipapar laserpunktur pada titik reproduksi. Disertasi. Pascasarjana Fakultas Perikanan dan Ilmu Kelautan. Universitas Brawijaya, Malang.

Kusuma, P.S.W. and D.Hariani. 2017.The role of laserpuncture exposure on gonad maturation mechanism of catfish (Clariassp.) through $\mathrm{Ca} 2+$, PKC and GABA neurotransmitter. Egytian Journal of Aquatic Research Vol. 43 :303-305.

Kusuma, P.S.W.,D.Hariani and Ngadiani. 2015. Utilization of Laserpuncture Induction as Spawning Stimulation in Catfish (Clarias spp.) Crossbreeding Toward Egg Quality. Egytian Journal of Aquatic Research Vol. 41: 353-358.

Ojutiku, R.O. 2008. Comparative Survival and Growth Rate of Clarias gariepinus and Heteroclarias Hathclings Fed Live and Frozen Daphnia. Pakistan $\mathbf{J}$ of Nutr 7 (4): 527-529.ISN 1680-5194.

Shinkafi, B.A. and J.K. Ipinjolu. 2012. Gonadosomatic index, fecundity and egg size of Auchenoglanis occidentalis (Cuvier and Valenciennes) in River Rima, North-Western Nigeria. Nigerian Journal of Basic and Applied Science, 20(3): 217-224.

Sotolu, A.O. 2010. Effects of varying dietary protein levels on the breeding performance of Clarias gariepinus broodstocks and fry growth rate. Livestock Research for Rural Development 22 (4) 2010. 
Weltzien, F-A., Norberg, B. and P. Swanson.2003. Isolation and characterization of FSH and LH from pituitary glands of Atlantic halibut (Hippoglossus hippoglossus L.). General and Compar Endocrinol 131.97-105.

Yaron, Z,.Gur G., Melamed P., Rosenfeld H, Elizur A and Levavi-Sivan B. 2003. Regulation of fish gonadotropins. Int Rev Cytol. 2003;225:131-85. 
VOL. 03. NO. 1, JANUARI 2019 